\title{
TECHNICAL, ECONOMIC AND ENVIRONMENTAL EFFICIENCY OF PRODUCTION OF SELECTED PLANT PRODUCTS IN THE AGRICULTURAL POLISH REGIONS
}

\begin{abstract}
The article presents regional differences in technical, economic and environmental efficiency of production of winter wheat, winter rye, spring barley, winter rape and sugar beet. The study used data collected in the AGROKOSZTY system and Polish FADN. Four-year averages were analysed to illustrate the changes in the results of the surveyed activities. The measure of technical efficiency was the productivity of factors of production (labour, land and capital), economic efficiency - profitability index, which expresses the ratio of production to economic costs. Whereas the environmental efficiency is described by indicators showing the cost and level of inputs adversely affecting the environment, i.e. mineral fertilisers (NPK) and plant protection products.

The results show significant regional differences. The technical efficiency of factors of production on farms located in the regions: Wielkopolska and Ślask, Pomorze and Mazury was higher than in Mazowsze and Podlasie and in the region of Małopolska and Pogórze. Land productivity showed the lowest level of variation in the regions. Economic production efficiency ranged from $97.1 \%$ to $147.5 \%$. Profitability index at the level of $97.1 \%$ was guaranteed by rye in the region of Małopolska and Pogórze, whose height means that the economic costs were not fully covered. For full coverage of the economic costs it would be necessary to increase the yield or price of rye grain by $4.5 \%$. Regional differences in the applied dose of NPK fertilisers in the cultivation of rye were 1.4 times, and in the case of other crops - 1.1 times.

While the cost of plant protection products varied more regionally. Differentiation of 1.1 times was observed only for sugar beet, in the case of
\end{abstract}


wheat and barley it amounted to 1.2 times, winter rape - 1.3 times, and rye - 2.3 times. In the region of Pomorze and Mazury, and Wielkopolska and Ślask the cost of plant protection products and NPK fertilisers per 1 ha of surveyed activities was mostly higher than in Mazowsze and Podlasie, and Małopolska and Pogórze.

Keywords: technical efficiency of factors of production, production profitability, environmental efficiency, economic costs of agricultural products, management income.

JEL Cods: D24, R11, O33.

\section{Introduction}

Plant production is crucial for human existence. It is necessary to make food of plant and animal origin. The level and structure of plant production depends on climate and soil, and economic and organisational conditions which influence the regional differences in the cropping structure, organisation and production intensity, yield level and marketability of production (Krasowicz and Kuś, 2006).

Agriculture, because of the production character, is strongly linked to land and the natural environment. However, the modern agricultural sector is increasingly more often based on the capital and information than on other factors of production and the competitive advantage of farms is progressively more dependent on the factor of knowledge that the farmers have (Coleman et al., 2004). This is linked to the functioning on the EU market and the possibility to benefit from several instruments of the Common Agricultural Policy. Thus, the efficiency of farming depends on factors of technical, production and economic character, but also on knowledge and skills in the field of management (Castle and Becker, 1971).

Efficiency - in general terms - is termed as the positive feature of measures giving a positive result, regardless of whether it was intentional (efficient and effective measure) or not (effective measure) (Czyżewski and Smędzik, 2010a). In agriculture, efficiency is determined by many factors that shape both the level of production and costs. Some of them are technical, others - economic, e.g. price-related (Czyżewski and Smędzik, 2010b). From the perspective of farms, economic efficiency of production is vital. It is defined as the difference between effects and incurred inputs. It ensures the possibility of survival on the market, which preconditions further development and building advantage in a competitive environment.

Recently, apart from economic production efficiency, environmental efficiency largely becomes the determinant of competitiveness in a long-term perspective. This phenomenon is even strengthened taking into account the fact that technological and organisational modifications in the production processes taking 
place on farms strongly affect its changes. Polish agriculture tries to overcome the challenges of competitiveness by a change in production scale and direction, and also by introduction of advanced technologies raising production efficiency and, at the same time, generating less environmental pollution (Jankowiak and Bieńkowski, 2010). Recently, the effects of agriculture intensification are increasingly clearer both in Poland and in other countries. The negative consequences of excessive mineral fertilisation and use of large quantities of chemical plant protection products is also gradually more and more common (Dincer, 2000; Runowski, 2002; Żak, 2016). Inappropriate use of industrial means of production, such as chemical fertilisers and plant protection products can lead to the disappearance of natural flora and fauna, disturbance of water management and microclimate, and consequently it can adversely impact many ecosystems.

In 2013, the annual average sales of plant protection products in the EU-28 per 1 ha of utilised agricultural area (UAA) was $2.0 \mathrm{~kg}$ of active substance (a.s.). In this respect Poland and Finland were ranked twelfth (1.5 kg of a.s.). The highest sales of plant protection products per 1 ha of UAA were noted in the Netherlands (5.8 kg of a.s.), Belgium (4.8 kg of a.s.), Italy (4.1 kg of a.s.) and Spain (3.0 kg of a.s.). For comparison, the lowest sales of pesticides was noted in Bulgaria - only $0.3 \mathrm{~kg}$ of a.s. per ha of UAA (Zalewski, 2016a). The consumption of mineral fertilisers in Poland is high. In the last several years it exceeded $100 \mathrm{~kg}$ of NPK per 1 ha of UAA. In the 2013/2014 season, Poland was ranked fourth among the EU-28countries, where the fertilisation level exceeded $100 \mathrm{~kg}$ of NPK per 1 ha of UAA (Belgium and Luxembourg - $183 \mathrm{~kg}$, Germany $-144 \mathrm{~kg}$, Croatia $-136 \mathrm{~kg}$, Poland $-133 \mathrm{~kg}$, the Netherlands $-127 \mathrm{~kg}$, Ireland $-120 \mathrm{~kg}$, France $-107 \mathrm{~kg}$, the Czech Republic - $103 \mathrm{~kg}$ ). The average mineral fertilisation level in the EU-28 countries (but also in the EU-15 and EU-13) amounted to $90 \mathrm{~kg}$ of NPK per 1 ha of UAA (Zalewski, 2016b).

When the consumption of chemical fertilisers is lower, the production results of field crops are often lower. However, yields can drop also when the optimum fertilisation threshold is exceeded. Sometimes higher consumption of chemical products is economically unjustified, because there are other environmental factors restricting plant yielding, e.g. soil acidification, water shortage (Popp and Hantos, 2011). In the recent years, the weather much deviates from what has been considered "normal" for decades. One of the key problems are yield losses due to unfavourable weather phenomena, such as thermal conditions, atmospheric precipitation, frequency and strength of extreme weather events (Tubiello et al., 2007).

The agriculture faces a dilemma: it is necessary to ensure a specific production level, but simultaneously it is vital to minimise the negative impact on the natural environment. The need for farming that protects the environment is evident. It was dictated by the increasing degradation of soils used for agricultural purposes and the increasing demand of the society for food with good quality parameters. 
The research, whose results are presented in the paper, aimed at assessment of the regional differentiation of the technical, economic and environmental efficiency of production of selected species of cereals, rape and sugar beet in Poland.

\section{Research material and method}

The research used data collected and processed in the AGROKOSZTY ${ }^{1}$ system which characterised selected plant production activities. To execute the purpose of the research, the data collected under the AGROKOSZTY system were supplemented with the data from the Polish FADN database, and then processed in line with cost account method developed for agricultural products. The analysis covered five plant production activities over four years of research (activities in the research of the AGROKOSZTY system repeat cyclically, usually at twoor three-year intervals), i.e.:

- Winter wheat, winter rye, winter rape - in 2006, 2008, 2011 and 2013;

- Spring barley - in 2007, 2009, 2011 and 2013;

- Sugar beet - in 2005, 2007, 2009 and 2014.

Four-year averages were analysed to illustrate the changes in the results of the surveyed production activities. Such an approach to the results eliminates the impact of accidental fluctuation possible in case of one-year averages (e.g. resulting from changes in the market or weather conditions). The number of farms in the research sample of the activity, in total over the years of the research was from 481 to 722 , respectively for rye and barley. These farms were grouped according to their regional location. The division of Poland into 4 regional units (Pomorze and Mazury, Wielkopolska and Sląsk, Mazowsze and Podlasie, Małopolska and Pogórze) was drawn up as part of adjustments of the Polish statistics to the EU standards ${ }^{2}$.

The research results were presented in tables. Horizontal analysis was also used; it compares the parameters characterising the surveyed activities on farms

\footnotetext{
${ }^{1}$ Research of agricultural production activities in the AGROKOSZTY system are held on individual farms selected under nonprobability sampling from a representative sample, which is in the field of observation of the Polish FADN. Such an approach is used to make it possible to supplement the database of the AGROKOSZTY system with the data from the Polish FADN. The selection of farms for the research of each production activity is done independently. The selection is conditioned on conducting the activity selected for the research and its determined production scale. Farms participating in the research are located across the country, but they are not - because of the sample selection method - a representative sample for individual farms in Poland conducting a specified activity, e.g. cultivation of winter wheat. The conducted research are fully voluntary and always require the farmer's consent. The AGROKOSZTY system collects quantitative and qualitative data on production, incurred inputs and direct costs as regards plant and animal production activity. The data are collected by uniform assumptions with precisely indicated standards and accurately determined methodology. They allow for calculation of gross margin.

${ }^{2}$ Agricultural regions cover the following voivodeships: Pomorze and Mazury - Lubuskie, Zachodniopomorskie, Pomorskie, Warmińsko-Mazurskie; Wielkopolska and Śląsk - Wielkopolskie, Kujawsko-Pomorskie, Dolnośląskie, Opolskie; Mazowsze and Podlasie - Podlaskie, Mazowieckie, Łódzkie, Lubelskie; Małopolska and Pogórze - Świętokrzyskie, Śląskie, Małopolskie, Podkarpackie.
} 
located in four agricultural regions. The research covered revenues, i.e. values of potentially commercial production, costs and economic effects. The level of gross margin and management income on activity less support with payments was taken as the measure of assessment of the obtained results. The manner of calculating these categories was presented below:

gross margin less payments $=$ production value (revenues) - direct costs

management income on activity less payments $=$ production value - economic costs.

In literature, economic cost is a term to describe full production cost (Samuelson and Nordhaus, 1995). Full cost accounting was taken as grounds for the conducted research. A farmer has the right to expect not only a coverage of costs of manufacture of goods, i.e. direct and indirect, but also should get a return on engaged own factors of production. Classical economics points to three factors, i.e. labour, land and capital. Their proper use should ensure management income to a farmer, i.e. remuneration for engagement in the production process of the knowledge, experience and management skills of the farmer. Costs of engagement of own factors of production are termed as opportunity costs. Opportunity cost is the value of the best not selected opportunity; it is assumed that respective goods could be used in other manner, which could bring greater benefits (income). This type of opportunity costs in monetary terms is known as implicit cost (i.e. implied cost) contrary to the recorded costs, i.e. actual cash expenses incurred which are termed as explicit costs (Milewski, 2008).

Direct costs are components which can be undoubtedly allocated to a given production activity, e.g. seed/grain material, fertilisers, plant protection products, insurance of a plantation. These costs have a proportional relationship with production scale and a direct impact on size (volume and value) of production. Indirect costs, however, are common for the entire farm. They include e.g. costs of electricity, fuel, current renovations of machines and buildings, depreciation of fixed assets and taxes. In line with the methodology used in the AGROKOSZTY system, indirect farm costs were broken down into production activities by the share of production value of each of them in the production value of the farm in total.

Costs of own factors of production are treated as opportunity costs. Own labour inputs were priced by the normative rate set based on the average remuneration level for a given year for farmers employed in the entire national economy, according to the data from the Central Statistical Office [Główny Urząd Statystyczny, GUS] (in subsequent years of the research the hourly rate amounted to: in 2005 - PLN 8.66; in 2006 - PLN 9.02; in 2007 - PLN 9.81; in 2008 - 10.74; in 2009 - PLN 11.31; in 2011 - PLN 12.38; in 2013 - PLN 13.79; in 2014. - PLN 14.29). The rental fee was taken as the measure of land cost. The method for determining the initial amount of the rental fee was based on the principles of determining the rental fee by the Agricultural Property 
Agency. The applied algorithm considers the type and class of land and the tax district in line with the principles binding upon calculation of the agricultural tax. Such an approach means that a major impact at the level of estimated land cost, apart from the soil valuation classes, falls to the regional location of farms which are in the research sample of respective production activities. The rental fee is expressed in natural units, i.e. in dt of wheat. The quantity of units depends on the soil class and tax district. In value terms, the amount of the rental fee was determined by the average price of buying-in of wheat in the country (according to GUS data). Capital cost encompasses operating capital and fixed capital costs. The value of inputs incurred on current production assets (e.g. seeds, fertilisers, plant protection products, fuel) were considered as the operating capital cost used to production. Whereas the cost of the fixed capital is the cost of capital invested in own fixed production assets (buildings, machines). Capital cost was estimated by the interest rate for deposits in the major commercial banks in Poland (according to GUS). It was assumed that the working capital was frozen for 6 months and the fixed capital for 1 year (Skarżyńska, 2010).

The research methods adopted in the paper enabled assessment of technical and economic efficiency of production of the research products. A measure of assessment of technical efficiency was productivity of the factors of production (in physical units), which was examined using technical efficiency measures, and technical efficiency of land was measured by yields of the researched plant production activities. Technical efficiency of labour was measured with the production volume from 1 ha per 1 hour of incurred labour inputs (own and hired) and technical efficiency of fixed assets was measured with the production volume per PLN 100 of the value of engaged fixed assets. Whereas economic efficiency assessment was measured with profitability index, which means a relation between the production value and economic costs.

It was also attempted to assess the environmental efficiency of manufacture of agricultural products. Environmental efficiency indices are expressed by costs and the level of inputs having a negative impact on the environment. The research used:

- Consumption of mineral fertilisers - NPK (in $\mathrm{kg}$ ) per 1 ha of cultivation of the surveyed activities;

- Cost of mineral fertilisers - NPK per 1 ha of cultivation of the surveyed activities;

- Cost of plant protection products per 1 ha of cultivation of the surveyed activities.

Environmental efficiency is also manifested in the relationship between the achieved effects and inputs adversely affecting the environment. The research used an index characterising technical efficiency of fertilisation. It illustrates the relation between the yield and the dose of NPK used per 1 ha of cultivation of the researched plant production activities. 


\section{Selected information about farms subject to research of agricultural products}

The research results indicate that the utilised agricultural area (UAA) of farms from the research sample of respective products was much differentiated in the regions. In Pomorze and Mazury, and Wielkopolska and Śląsk it was larger than in Mazowsze and Podlasie, and Małopolska and Pogórze. Comparing extreme values the difference was from 1.9 times to 2.4 times. This involves the agrarian structure of farms in separated regions. UAA was one of the parameters that were used upon selection of uniform agricultural regions in Poland (Skarżyńska et al., 2005).

The regional differences concerned also the area under cultivation of the researched field crops. In Pomorze and Mazury, and Wielkopolska and Śląsk it was larger than in the two other regions. The research shows that larger area contributed to a drop in labour-intensity of cultivation which means that the labour force was used more effectively. The share of own labour in total labour also decreased.

The share of plant production in the total production value structure of farms from the research sample cultivating winter wheat, winter rape and sugar beet was equal to or higher than $70 \%$. This means that plant production predominated in all regions. For farms cultivating winter rye and spring barley the share in the structure of plant and animal production value was basically fluctuating around $50 \%$. Only for farms cultivating spring barley in Małopolska and Pogórze, and Wielkopolska and Śląsk there was some advantage of plant production. Its share was at $64.0 \%$ and $58.7 \%$, respectively (Table 1 ).

The share of production value generated by rye and wheat production in the total production value of farms in all regions was close and within the range of $6.1-8.5 \%$. Hence, it can be considered that their significance was similar. As regards other products, there are clear differences. The importance of wheat and rape in Małopolska and Pogórze was lower than in other regions (the share was $17.7 \%$ and $14.6 \%$ ). But then, the significance of sugar beet cultivation was the lowest on farms located in Wielkopolska and Śląsk. Its share in the structure of production value of a farm was $16.5 \%$, while in other regions it was within the range of 21.9-24.8\%. This was determined by the results of surveyed activities, but also other activities conducted on the farms. It should be added that differences are clear also upon comparison of activities between each other. The share of revenues on wheat, rape and sugar beet in total revenues of farms was higher than the share of revenues from rye and barley cultivation. 
Table 1

Selected information about farms cultivating the researched plant production activities in agricultural regions of Poland, average in years of research

\begin{tabular}{|c|c|c|c|c|}
\hline Specification & $\begin{array}{c}\text { Pomorze } \\
\text { and Mazury }\end{array}$ & $\begin{array}{c}\text { Wielkopolska } \\
\text { and Sląsk }\end{array}$ & $\begin{array}{c}\text { Mazowsze } \\
\text { and Podlasie }\end{array}$ & $\begin{array}{l}\text { Małopolska } \\
\text { and Pogórze }\end{array}$ \\
\hline & \multicolumn{4}{|c|}{ Winter wheat } \\
\hline Number of surveyed farms, total in years & 120 & 188 & 161 & 133 \\
\hline Utilised agricultural area (UAA), ha/farm & 101.38 & 79.78 & 52.01 & 64.50 \\
\hline Cultivation area, ha/farm & 30.17 & 24.28 & 16.71 & 16.24 \\
\hline Selling price of grain, PLN/dt & 60.64 & 62.27 & 64.30 & 61.65 \\
\hline Total labour input, hour/ha & 9.7 & 9.5 & 10.6 & 10.8 \\
\hline including: share of own labour input, $\%$ & 91.3 & 83.4 & 88.9 & 92.0 \\
\hline \multicolumn{5}{|c|}{ Share in production value structure of a farm, $\%$} \\
\hline - plant production & 80.4 & 72.6 & 72.0 & 70.4 \\
\hline - animal production & 18.8 & 26.6 & 26.4 & 28.3 \\
\hline \multirow{2}{*}{ - surveyed activity } & 26.6 & 22.1 & 21.2 & 17.7 \\
\hline & \multicolumn{4}{|c|}{ Winter rye } \\
\hline Number of surveyed farms, total in years & 133 & 109 & 195 & 44 \\
\hline Utilised agricultural area (UAA), ha/farm & 101.47 & 71.02 & 41.79 & 46.82 \\
\hline Cultivation area, ha/farm & 16.17 & 11.15 & 7.57 & 7.14 \\
\hline Selling price of grain, PLN/dt & 46.55 & 51.59 & 52.54 & 46.44 \\
\hline Total labour input, hour/ha & 8.0 & 9.9 & 9.4 & 11.6 \\
\hline including: share of own labour input, $\%$ & 84.6 & 76.5 & 92.8 & 91.2 \\
\hline \multicolumn{5}{|c|}{ Share in production value structure of a farm, $\%$} \\
\hline - plant production & 53.1 & 50.7 & 47.0 & 55.0 \\
\hline - animal production & 46.3 & 48.2 & 51.1 & 44.2 \\
\hline \multirow[t]{2}{*}{ - surveyed activity } & 7.3 & 6.3 & 6.3 & 6.1 \\
\hline & \multicolumn{4}{|c|}{ Spring barley } \\
\hline Number of surveyed farms, total in years & 144 & 237 & 178 & 163 \\
\hline Utilised agricultural area (UAA), ha/farm & 82.54 & 78.69 & 41.36 & 51.29 \\
\hline Cultivation area, ha/farm & 12.87 & 12.79 & 7.23 & 8.52 \\
\hline Selling price of grain, PLN/dt & 57.13 & 61.11 & 60.29 & 59.60 \\
\hline Total labour input, hour/ha & 7.8 & 7.7 & 8.9 & 9.7 \\
\hline including: share of own labour input, $\%$ & 85.8 & 85.0 & 95.3 & 96.0 \\
\hline \multicolumn{5}{|l|}{ Share in production value structure of a farm, $\%$} \\
\hline - plant production & 53.6 & 58.7 & 50.9 & 64.0 \\
\hline - animal production & 45.6 & 40.5 & 47.4 & 34.5 \\
\hline \multirow[t]{2}{*}{ - surveyed activity } & 8.2 & 7.3 & 7.6 & 8.5 \\
\hline & \multicolumn{4}{|c|}{ Winter rape } \\
\hline Number of surveyed farms, total in years & 146 & 206 & 122 & 79 \\
\hline Utilised agricultural area (UAA), ha/farm & 107.78 & 82.84 & 56.31 & 75.07 \\
\hline Cultivation area, ha/farm & 22.01 & 18.82 & 12.22 & 13.69 \\
\hline Selling price of seeds, PLN/dt & 130.85 & 138.43 & 134.84 & 134.83 \\
\hline Total labour input, hour/ha & 8.9 & 9.4 & 9.8 & 10.4 \\
\hline including: share of own labour input, $\%$ & 85.4 & 82.2 & 93.5 & 92.9 \\
\hline \multicolumn{5}{|l|}{ Share in production value structure of a farm, $\%$} \\
\hline - plant production & 72.1 & 73.2 & 79.4 & 70.7 \\
\hline - animal production & 27.2 & 25.9 & 19.2 & 28.2 \\
\hline \multirow[t]{2}{*}{ - surveyed activity } & 18.2 & 19.9 & 16.4 & 14.6 \\
\hline & \multicolumn{4}{|c|}{ Sugar beets } \\
\hline Number of surveyed farms, total in years & 109 & 235 & 156 & 73 \\
\hline Utilised agricultural area (UAA), ha/farm & 90.26 & 80.91 & 44.68 & 46.80 \\
\hline Cultivation area, ha/farm & 12.24 & 9.59 & 7.34 & 8.12 \\
\hline Selling price of roots, PLN/dt & 12.54 & 12.71 & 13.30 & 13.19 \\
\hline Total labour input, hour/ha & 27.2 & 28.8 & 47.3 & 38.8 \\
\hline including: share of own labour input, $\%$ & 65.3 & 64.3 & 90.9 & 70.1 \\
\hline \multicolumn{5}{|c|}{ Share in production value structure of a farm, $\%$} \\
\hline - plant production & 80.6 & 72.9 & 69.9 & 70.1 \\
\hline - animal production & 18.8 & 26.4 & 28.9 & 29.0 \\
\hline - surveyed activity & 21.9 & 16.5 & 22.8 & 24.8 \\
\hline
\end{tabular}

Source: drawn up on the basis of data from the AGROKOSZTY system and Polish FADN. 
In case of cereals the highest prices for sold grain were obtained by farmers from Wielkopolska and Śląsk, and Mazowsze and Podlasie. The highest price for rape seeds was obtained by farms in Wielkopolska and Śląsk, and for roots of the sugar beet in two regions: Mazowsze and Podlasie, and Małopolska and Pogórze (Table 1).

\section{Technical efficiency of factors of production}

Technical efficiency refers to conversion of resources into a specified final product. It is based on technological production possibilities, i.e. it involves the use of resources in the technologically most efficient manner and it is not linked to the level of prices and costs. Technical efficiency is a prerequisite to achieve economic efficiency, but this does not mean that all technically efficient solutions are also economically efficient. The technical efficiency means that an increase in the quantity of manufactured products without greater involvement of factors of production is impossible; thus, it is one of the manifestations of the farm management system and assessment and measurement of achievements.

Technical efficiency of production activities is the greater, the greater is the production effect obtained at the given level of inputs and applied factors of production.

Considering the technical efficiency of factors of production involved in the production process, there is a clear regional differentiation of productivity of land under cultivation of the surveyed cereals, rape and sugar beet. However, it needs to be noted that among the analysed types of production it was marked by the lowest scale of differentiation. This differentiation, at least to some extent, was predetermined by regional location of farms, i.e. mainly the used technology and agro-climatic conditions (e.g. land insolation and humidity, number of growing days, temperature). In Wielkopolska and Śląsk, and Pomorze and Mazury - against two other regions - land productivity was on the upper level. These regions were marked by a special advantage in case of land under cultivation of winter wheat, winter rye, winter rape and sugar beet - Table 2 .

Taking into account different labour-intensity of cultivation and different level of obtained production, it is clear that there are great disproportions in labour productivity between regions. Farms situated in the Pomorze and Mazury, and Wielkopolska and Śląsk should be mentioned because there it was relatively high, while in the two other regions it was much lower. Given the extreme values, the difference in labour productivity incurred on winter wheat production was 1.2 times, spring barley and winter rape -1.3 times, winter rye -1.7 times and sugar beet -1.8 times.

Productivity of fixed assets was also different in the regions. Farms situated in Mazowsze and Podlasie, and Małopolska and Pogórze obtained a weaker result than units from Pomorze and Mazury, and Wielkopolska and Śląsk, which evidences a rather heavy burdening of the surveyed activities with fixed assets. 
Productivity of fixed assets engaged in production of winter wheat, winter rye and sugar beet was the lowest in Mazowsze and Podlasie. Compared to the highest level (for cereals in Pomorze and Mazury, and sugar beet - in Wielkopolska and Śląsk) it was lower by, respectively, $32.0 \%$; $39.5 \%$ and $25.6 \%$. Whereas productivity of fixed assets involved in spring barley and winter rape production was at a relatively low level and at identical level in Mazowsze and Podlasie, and Małopolska and Pogórze. As regards the highest level, it was lower by $23.7 \%$ in Wielkopolska and by $20.0 \%$ in Śląsk (Table 2).

Table 2

Technical efficiency of factors of production participating in the production process of the surveyed products in the agricultural regions of Poland, average in research years

\begin{tabular}{|c|c|c|c|c|}
\hline Specification & $\begin{array}{c}\text { Pomorze } \\
\text { and Mazury }\end{array}$ & $\begin{array}{c}\text { Wielkopolska } \\
\text { and Sląsk }\end{array}$ & $\begin{array}{c}\text { Mazowsze } \\
\text { and Podlasie }\end{array}$ & $\begin{array}{l}\text { Małopols } \\
\text { and Pogó }\end{array}$ \\
\hline & \multicolumn{4}{|c|}{ LAND - production in dt per 1 ha of cultivation } \\
\hline Winter wheat & 57.4 & 57.3 & 52.5 & 53.8 \\
\hline Winter rye & 34.3 & 31.3 & 28.1 & 29.1 \\
\hline Spring barley & 37.3 & 43.6 & 40.0 & 42.9 \\
\hline Winter rape & 28.9 & 32.7 & 28.8 & 27.6 \\
\hline \multirow[t]{2}{*}{ Sugar beets } & 581 & 569 & 572 & 457 \\
\hline & \multicolumn{4}{|c|}{ LABOUR - production in dt per 1 hour of total labour inp } \\
\hline Winter wheat & 5.94 & 6.06 & 4.97 & 5.00 \\
\hline Winter rye & 4.33 & 3.17 & 2.98 & 2.50 \\
\hline Spring barley & 4.78 & 5.65 & 4.48 & 4.42 \\
\hline Winter rape & 3.25 & 3.48 & 2.93 & 2.66 \\
\hline \multirow[t]{2}{*}{ Sugar beets } & 21.33 & 19.73 & 12.09 & 11.79 \\
\hline & \multicolumn{4}{|c|}{ FIXED ASSETS - production in dt per PLN 100 of fixed assets } \\
\hline Winter wheat & 1.03 & 1.01 & 0.70 & 0.79 \\
\hline Winter rye & 1.24 & 0.99 & 0.75 & 0.85 \\
\hline Spring barley & 0.94 & 1.14 & 0.87 & 0.87 \\
\hline Winter rape & 0.50 & 0.50 & 0.40 & 0.40 \\
\hline Sugar beets & 5.33 & 5.50 & 4.09 & 5.24 \\
\hline
\end{tabular}

Source: drawn up based on own research.

Lower productivity of fixed assets in Mazowsze and Podlasie, and Małopolska and Pogórze was, to some extent determined, by the level of obtained production, but the determining factor was much greater burdening of the researched activities with the value of owned buildings and structures, and machines and means of transport. This is also evidenced by their value per 1 ha of UAA of farms from the research sample (Table 3). 
Table 3

Value of buildings and structures and machines and means of transport (PLN/ha of UAA) on farms running surveyed activities in agricultural regions of Poland, on average in research years

\begin{tabular}{lcccc}
\hline \multicolumn{1}{c}{ Specification } & $\begin{array}{c}\text { Pomorze } \\
\text { and Mazury }\end{array}$ & $\begin{array}{c}\text { Wielkopolska } \\
\text { and Sląsk }\end{array}$ & $\begin{array}{c}\text { Mazowsze } \\
\text { and Podlasie }\end{array}$ & $\begin{array}{c}\text { Małopolska } \\
\text { and Pogórze }\end{array}$ \\
\hline Winter wheat & 6562 & 7820 & 10131 & 9439 \\
Winter rye & 5225 & 8573 & 9099 & 7643 \\
Spring barley & 6646 & 7744 & 10632 & 9901 \\
Winter rape & 6347 & 7857 & 9194 & 8773 \\
Sugar beets & 5656 & 5336 & 7491 & 7575
\end{tabular}

Source: drawn up based on own research.

The value of buildings and structures, and machines and means of transport per 1 ha of UAA in groups of farms running the surveyed plant production activities in Mazowsze and Podlasie was the highest (the only exception were farms cultivating sugar beet). Second, in terms of burdening with the value of these fixed assets, were farms in Małopolska and Pogórze (except for farms cultivating winter rye). The ownership of fixed assets in value terms was much lower in Wielkopolska and Śląsk, and Pomorze and Mazury.

It was assessed that the value of fixed assets on farms is - at least to some extent - linked to running animal production which determined a specific level of equipment. This refers especially to farms situated in Mazowsze and Podlasie, many of which specialise in milk production and keep large herds of dairy cows. Plant production activities are often conducted to secure fodder resources for animals, but can also affect the provision of farms with both specialist machines and buildings.

Investments in resources of fixed assets on farms are linked to incurring large one-off expenses, and then with burdening the conducted production activities with costs of keeping such assets ready for production. Consequently, the efficiency of conducted activity can be lower. In this situation, the range of decisions increasing technical efficiency cover decisions on an increase in production scale and specialisation. In this context, it needs to be noted that the area of cultivation of surveyed activities on farms in Mazowsze and Podlasie, and Małopolska and Pogórze was much lower than in Pomorze and Mazury, and Wielkopolska and Śląsk.

\section{Economic efficiency of production}

Economic efficiency derives from the principle of rational management and means achievement of specified results at possibly the lowest inputs (costs) or achievement of possibly the best results from a given amount of inputs. Eco- 
nomic efficiency reaches deeper than technical efficiency, as it depends on prices of factors of production. This means that something which is technically efficient, does not have to be economically efficient. Economic efficiency is linked to optimum allocation of factors of production. This can be illustrated on the example of a change in the relation between the labour factor and fixed assets, which can contribute to reduction in costs and thus to a growth in efficiency of conducted production.

Table 4 presents the level of potentially commercial production value (revenues) on surveyed products, costs incurred on its manufacturing, economic margin left for disposal of the farmer and profitability of production captured as relation, which is expressed by the profitability index illustrating the level of coverage of economic costs with production value. The presented calculations also point to regional differences in respective categories.

Analysing the revenues on surveyed products and comparing in the regions their maximum to minimum level, the difference was from $5.6 \%$ for sugar beet to $25.7 \%$ for spring barley. A similar difference in the amount of economic costs was within the range of 5.4-15.2\%, respectively, as regards spring barley and winter rape.

Differences in production value and incurred costs result in differences in income level. Taking into account gross margin and management income less payments, what draws attention is the regularity which concerns four among five of the surveyed products (with the exception of sugar beet). In regions where cereals and rape ensured the highest direct surplus, the management income less payments was also the highest. This means that the impact of indirect costs and cost of factors of production was not strong enough to cause the change. Consequently, gross margin - which is the difference between the production value and direct costs - determined the level of management income. Cultivation of winter wheat and winter rye helped to achieve income at the highest level for farms in Pomorze and Mazury, and Wielkopolska and Śląsk, while spring barley cultivation for farms in Wielkopolska and Śląsk, Małopolska and Pogórze, and winter rape - in Wielkopolska and Śląsk, Mazowsze and Podlasie. In these regions, the production profitability index was also the highest.

In case of sugar beet the highest gross margin was obtained by growers from Mazowsze and Podlasie, and Małopolska and Pogórze. Whereas at the level of management income there is a clear change - the position of Mazowsze and Podlasie was taken by farms from Pomorze and Mazury. This was conditioned upon relatively high indirect costs and costs of factors of production in Mazowsze and Podlasie. At the level of indirect costs, the impact of costs of depreciation of engaged fixed assets had a crucial impact, and high cost of factors of production determined the cost of own labour. The production profitability index for sugar beet was the highest in Małopolska and Pogórze (147.5\%), and the lowest in Mazowsze and Podlasie (136.5\%) - Table 4. 
Table 4

Economic efficiency of production of surveyed products in agricultural regions of Poland, on average in research years

\begin{tabular}{|c|c|c|c|c|}
\hline Specification & $\begin{array}{c}\text { Pomorze } \\
\text { and Mazury }\end{array}$ & $\begin{array}{c}\text { Wielkopolska } \\
\text { and Śląsk }\end{array}$ & $\begin{array}{c}\text { Mazowsze } \\
\text { and Podlasie }\end{array}$ & $\begin{array}{l}\text { Małopolska } \\
\text { and Pogórze }\end{array}$ \\
\hline & \multicolumn{4}{|c|}{ Winter wheat } \\
\hline Production value (WP), PLN/ha & 3541 & 3610 & 3442 & 3337 \\
\hline Economic costs (KE), PLN/ha & 2662 & 2821 & 2755 & 2660 \\
\hline including: direct costs & 1190 & 1253 & 1158 & 1184 \\
\hline indirect costs & 1090 & 1162 & 1178 & 1064 \\
\hline costs of factors of production & 382 & 406 & 419 & 412 \\
\hline Gross margin less payments, PLN/ha & 2351 & 2357 & 2284 & 2153 \\
\hline Management income less payments, PLN/ha & 879 & 790 & 687 & 677 \\
\hline \multirow[t]{2}{*}{ Profitability index (WP/KE), $\%$} & 133.0 & 128.0 & 124.9 & 125.5 \\
\hline & \multicolumn{4}{|c|}{ Winter rye } \\
\hline Production value (WP), PLN/ha & 1640 & 1637 & 1448 & 1371 \\
\hline Economic costs (KE), PLN/ha & 1451 & 1440 & 1287 & 1412 \\
\hline including: direct costs & 635 & 659 & 478 & 540 \\
\hline indirect costs & 589 & 549 & 577 & 593 \\
\hline costs of factors of production & 227 & 231 & 232 & 279 \\
\hline Gross margin less payments, PLN/ha & 1005 & 978 & 969 & 831 \\
\hline Management income less payments, PLN/ha & 189 & 197 & 161 & -41 \\
\hline \multirow[t]{2}{*}{ Profitability index (WP/KE), \% } & 113.0 & 113.7 & 112.5 & 97.1 \\
\hline & \multicolumn{4}{|c|}{ Spring barley } \\
\hline Production value (WP), PLN/ha & 2119 & 2663 & 2424 & 2590 \\
\hline Economic costs (KE), PLN/ha & 1848 & 1944 & 1844 & 1928 \\
\hline including: direct costs & 833 & 860 & 795 & 798 \\
\hline indirect costs & 762 & 764 & 746 & 768 \\
\hline costs of factors of production & 254 & 320 & 303 & 362 \\
\hline Gross margin less payments, PLN/ha & 1286 & 1803 & 1629 & 1792 \\
\hline Management income less payments, PLN/ha & 271 & 719 & 580 & 662 \\
\hline \multirow[t]{2}{*}{ Profitability index (WP/KE), $\%$} & 114.6 & 137.0 & 131.5 & 134.3 \\
\hline & \multicolumn{4}{|c|}{ Winter rape } \\
\hline Production value (WP), PLN/ha & 3697 & 4403 & 3836 & 3875 \\
\hline Economic costs (KE), PLN/ha & 3059 & 3298 & 2862 & 3036 \\
\hline including: direct costs & 1571 & 1576 & 1300 & 1377 \\
\hline indirect costs & 1139 & 1331 & 1211 & 1254 \\
\hline costs of factors of production & 350 & 391 & 351 & 405 \\
\hline Gross margin less payments, PLN/ha & 2126 & 2827 & 2536 & 2499 \\
\hline Management income less payments, PLN/ha & 638 & 1105 & 974 & 840 \\
\hline \multirow[t]{2}{*}{ Profitability index (WP/KE), \% } & 120.9 & 133.5 & 134.0 & 127.7 \\
\hline & \multicolumn{4}{|c|}{ Sugar beets } \\
\hline Production value (WP), PLN/ha & 7241 & 7086 & 7482 & 7127 \\
\hline Economic costs (KE), PLN/ha & 5067 & 4957 & 5481 & 4832 \\
\hline including: direct costs & 2465 & 2320 & 2459 & 2282 \\
\hline indirect costs & 2158 & 2209 & 2399 & 2014 \\
\hline costs of factors of production & 445 & 428 & 623 & 536 \\
\hline Gross margin less payments, PLN/ha & 4776 & 4766 & 5023 & 4845 \\
\hline Management income less payments, PLN/ha & 2173 & 2129 & 2001 & 2294 \\
\hline Profitability index (WP/KE), \% & 142.9 & 142.9 & 136.5 & 147.5 \\
\hline
\end{tabular}

Source: drawn up based on own research. 
Wheat, barley, rape and sugar beet cultivation on average over the years and in the research sample of farms in all regions ensured margin in the form of management income. The only exception was rye cultivation in Małopolska and Pogórze, for which the income was not executed; the loss amounted to PLN 41 per ha. In this case, full coverage of the costs of own factors of production, i.e. labour, land and capital, was not possible. For full coverage of the economic costs it would be necessary to increase yield or prices of seed sales by $4.5 \%$ (the yield should amount to $30.4 \mathrm{dt}$ per ha or the price to - PLN $48.52 \mathrm{per} \mathrm{dt}$ ).

Production profitability measured with the relation of production value to economic costs showed that among the surveyed products the highest profitability was typical of sugar beet cultivation (136.5-147.5\%), and the lowest - rye cultivation (97.1-113.7\%).

A measure reflecting the production side and cost side of surveyed products is also the level of economic costs that had to be engaged in generation of PLN 1 of management income less payments. Differentiation in results is major, both between products and in the regions. The cost of production of PLN 1 of management income in the regions was within the rage of:

- PLN 3.0-4.0 for winter wheat,

- PLN 7.3-8.0 for winter rye (except for Małopolska and Pogórze),

- PLN 2.7-6.8 for spring barley,

- PLN 2.9-4.8 for winter rape,

- PLN 2.1-2.7 for sugar beet.

The cost of generation of PLN 1 of management income was the highest for rye cultivation and the lowest for sugar beet. Whereas the greatest differences in the regions, comparing extreme levels of the cost, were noted in case of barley (2.5 times), and the lowest - rye (1.1 times) - Table 4 .

\section{Environmental efficiency}

In the research, the basic measure of environmental efficiency was consumption or cost of mineral fertilisers and plant protection products introduced to the environment as a result of intentional human activity. An additional measure was technical efficiency of applied fertilisation.

The cost of mineral fertilisers and plant protection products are components that clearly dominate in the structure of direct costs. In the case of researched products in regional terms, their total share was from $67.0 \%$ to $83.7 \%$. Differences in the cost of mineral fertilisers in the regions resulted mainly from differences in the size of applied NPK dose, although it was also influenced by the type structure of used fertilisers and their purchase price. Whereas the reason for differentiation of the cost of plant protection products (pesticides) could have been the difference in the price of purchase of these products, but it is assessed the number of conducted protection treatments, which was linked to the amount of used active substance, had the decisive impact. 
Taking into account the extreme values, the regional differences in the applied dose of NPK in the cultivation of rye was 1.4 times, and in the case of other crops - 1.1 times. Research showed that in Pomorze and Mazury, and Wielkopolska and Śląsk the highest level of fertilisation was used for cultivation of rye, spring barley and winter rape. In Mazowsze and Podlasie, winter wheat fertilisation was at a high level $(261 \mathrm{~kg} / \mathrm{ha})$, and in the region of Małopolska and Pogórze - sugar beet fertilisation $(390 \mathrm{~kg} / \mathrm{ha})$. Whereas the lowest level of fertilisation was applied by farmers cultivating winter wheat and spring barley and winter rape in Małopolska and Pogórze (it amounted, respectively, to 239, 159 and $299 \mathrm{~kg} / \mathrm{ha}$ ) - Table 5.

Table 5

Environmental efficiency of production of surveyed products in agricultural regions of Poland, on average in research years

\begin{tabular}{|c|c|c|c|c|}
\hline Specification & $\begin{array}{c}\text { Pomorze } \\
\text { and Mazury }\end{array}$ & $\begin{array}{c}\text { Wielkopolska } \\
\text { and Sląsk }\end{array}$ & $\begin{array}{c}\text { Mazowsze } \\
\text { and Podlasie }\end{array}$ & $\begin{array}{r}\text { Małopolska } \\
\text { and Pogórze }\end{array}$ \\
\hline & \multicolumn{4}{|c|}{ Consumption of NPK per 1 ha of cultivation $(\mathrm{kg})$} \\
\hline Winter wheat & 251 & 254 & 261 & 239 \\
\hline Winter rye & 143 & 158 & 115 & 124 \\
\hline Spring barley & 177 & 177 & 175 & 159 \\
\hline Winter rape & 328 & 339 & 307 & 299 \\
\hline \multirow[t]{2}{*}{ Sugar beets } & 371 & 362 & 383 & 390 \\
\hline & \multicolumn{4}{|c|}{ Cost of NPK per 1 ha of cultivation (PLN) } \\
\hline Winter wheat & 641 & 664 & 662 & 618 \\
\hline Winter rye & 387 & 399 & 304 & 338 \\
\hline Spring barley & 522 & 522 & 490 & 453 \\
\hline Winter rape & 857 & 882 & 752 & 807 \\
\hline \multirow[t]{2}{*}{ Sugar beets } & 933 & 943 & 963 & 898 \\
\hline & \multicolumn{4}{|c|}{ Technical efficiency of fertilisation (production in $\mathrm{kg}$ per $1 \mathrm{~kg}$ of NPK } \\
\hline Winter wheat & 23.2 & 22.7 & 20.3 & 22.6 \\
\hline Winter rye & 24.4 & 21.1 & 24.7 & 24.4 \\
\hline Spring barley & 21.1 & 24.7 & 22.9 & 27.5 \\
\hline Winter rape & 8.9 & 9.6 & 9.4 & 9.2 \\
\hline \multirow[t]{2}{*}{ Sugar beets } & 159.7 & 157.3 & 152.9 & 151.9 \\
\hline & \multicolumn{4}{|c|}{ Cost of plant protection products per 1 ha of cultivation (PLN) } \\
\hline Winter wheat & 297 & 313 & 272 & 304 \\
\hline Winter rye & 100 & 110 & 47 & 64 \\
\hline Spring barley & 124 & 142 & 138 & 133 \\
\hline Winter rape & 421 & 394 & 336 & 315 \\
\hline Sugar beets & 535 & 493 & 469 & 475 \\
\hline
\end{tabular}


Regional differentiation of the cost of NPK dose used per 1 ha of cultivation of winter wheat or sugar beet amounted to 1.1 times, while in case of cultivation of spring barley and winter rape -1.2 times, and rye -1.3 times. Research shows that the cost of plant protection products also differed in the regions. Differences amounting to 1.1 times was noted only for sugar beet. For wheat and barley the differentiation amounted to 1.2 times and for winter rape -1.3 times, and rye -2.3 times.

As regards the amount of costs of plant protection products - similarly as in the case of the cost of NPK - the region of Pomorze and Mazury, and Wielkopolska and Śląsk stand out. In both regions, the highest cost of the plant protection products was incurred by farmers in case of cultivation of rye, winter rape and sugar beet, while in Wielkopolska and Śląsk also for the cultivation of winter wheat and spring barley. The cost of plant protection products was the lowest in Mazowsze and Podlasie on farms cultivating winter wheat, rye and sugar beet, and in the Małopolska and Pogórze - winter rape.

In the research the assessment covered also the technical efficiency of fertilisation used in cultivation of the surveyed field crops. According to literature, the interrelation between the plant yield size and the dose of fertilisation component is very complicated and depends on many factors (e.g. forecrop, soil conditions and fertility, soil reaction, quantity and distribution of precipitation, number and size of fertiliser doses, and term of using them, ratio of fertilisation components $\mathrm{N}: \mathrm{P}: \mathrm{K})$. Some level of yield can be also achieved without fertilisation - it is the effect of natural soil fertility. The same effect of yield can be achieved using a relevant or even several times higher dose of fertilisers. Fertilisation, instead of a positive effect, can cause also a drop in yields (Gębska and Filipiak, 2006).

Research results point to differences in the technical efficiency of fertilisation in the regions, and additionally most often to a lack of direct connection with the applied dose of NPK. Only on farms cultivating winter rape in Wielkopolska and Sląsk, where fertilisation was the highest, its technical efficiency was also the highest $-9.6 \mathrm{~kg}$ of seed per $1 \mathrm{~kg}$ of NPK (in the remaining regions it was within the range of 8.8-9.4 kg). In case of the remaining products, no such interrelation was found. In Mazowsze and Podlasie the NPK dose applied for cultivation of winter wheat was the highest $(261 \mathrm{~kg} / \mathrm{ha})$, while technical efficiency of fertilisation - the lowest (20.1 kg of seed per $1 \mathrm{~kg}$ of NPK). This also referred to the cultivation of rye, barley and sugar beet. It can be assumed that unfavourable layout of other factors affecting the agrosystem contributed thereto.

\section{Conclusions}

The area under cultivation of the surveyed field crops, i.e. winter wheat, winter rye, spring barley, winter rape and sugar beet, differed across the regions. For farms located in the regions of Pomorze and Mazury, and Wielkopolska and Śląsk, it was larger than in Mazowsze and Podlasie, and Małopolska and 
Pogórze. The larger cultivation area contributed to a drop in labour-intensity which means that the labour force was used more effectively, which in turn influenced technical efficiency (productivity) of the labour factor.

The research of technical efficiency of factors of production, i.e. land, labour and fixed assets, engaged in the production processes showed differences in the regions. The smallest scale of differentiation was typical of land productivity. These differences, at least partly, were predetermined by the location of farms, i.e. primarily the applied technology and agroclimate conditions. In Wielkopolska and Śląsk, and Pomorze and Mazury land productivity was higher than in the two other regions. A special advantage - to the benefit of these regions - was noted for land under cultivation of winter wheat, rye, winter rape and sugar beet. As regards technical productivity of labour, what should be also mentioned are the farms in Wielkopolska and Sląsk, and Pomorze and Mazury. This was preconditioned by lower labour-intensity of cultivation and most often higher productivity of land. Efficiency of fixed assets engaged in the production process was also higher in these regions. Farms located in Mazowsze and Podlasie, and Małopolska and Pogórze had a weaker result. Lower level of obtained production contributed thereto, but the key factor was higher burdening with the condition of owned fixed assets (in value terms). It is assessed that - at least to some extent - this is linked to running animal production which determined a specific level of equipment provision on farms. This especially refers to farms situated in Mazowsze and Podlasie, many of which specialise in milk production.

Research aiming at assessment of economic efficiency of production showed that cultivation of winter wheat and winter rye helped to achieve gross margin and management income less subsidies at the highest level for farms in Pomorze and Mazury, and Wielkopolska and Śląsk, while spring barley cultivation for farms in Wielkopolska and Śląsk, and Małopolska and Pogórze, and winter rape - in Wielkopolska and Śląsk, and Mazowsze and Podlasie. In these regions, the production profitability index was also the highest. This means that gross margins to some extent determined profitability at the level of management income. For sugar beet, the case was opposite. The highest gross margin was obtained by growers from Mazowsze and Podlasie, and Małopolska and Pogórze. Whereas at the level of management income - the position of Mazowsze and Podlasie was taken by farms from Pomorze and Mazury. This was conditioned upon relatively high indirect costs and high costs of factors of production in Mazowsze and Podlasie. At the level of indirect costs, the impact of costs of depreciation of engaged fixed assets had a crucial impact, and high cost of factors of production determined the cost of own labour. Only rye cultivation in Małopolska and Pogórze failed to ensure margin in the form of management income less payments; the loss amounted to PLN 41 per ha. Production profitability index, which shows the relation between production value and economic costs, amounted to $97.1 \%$. Given all types of activities, in regional terms this index was within the range of 97.1-147.5\%. 
A measure of assessment of environmental efficiency of production of surveyed products was consumption or cost of mineral fertilisers and plant protection products introduced into the environment. Research showed that Pomorze and Mazury, and Wielkopolska and Śląsk used the highest level of fertilisation for cultivation of rye, spring barley and winter rape. In Mazowsze and Podlasie the fertilisation of winter wheat was at a high level, and in the region of Małopolska and Pogórze - sugar beet. Despite differences, regional differentiation in the applied dose of NPK was most often not very high, in the cultivation of rye it amounted to 1.4 times, and in the case of other field crops -1.1 times. Whereas the cost of plant protection products greatly varied in the regions. Differentiation of 1.1 times was observed only for sugar beet, in the case of wheat and barley it was 1.2 times, winter rape -1.3 times and rye -2.3 times. A relatively high cost of plant protection products was noted on farms in Pomorze and Mazury, and Wielkopolska and Sląsk. In both regions, the highest cost was incurred by farmers in case of cultivation of rye, winter rape and sugar beet, while in Wielkopolska and Śląsk also for the cultivation of winter wheat and spring barley. The cost of plant protection products was the lowest in Mazowsze and Podlasie on farms cultivating winter wheat, rye and sugar beet, and in the Małopolska and Pogórze - winter rape.

European integration and globalisation stimulate many changes in the Polish agriculture. There is a chance for survival in the market for farmers that will meet the challenge of reducing production costs, increasing scale and efficiency of production and improving the quality of manufactured products. In the agricultural sector, the production effects are often linked to simultaneous creation of different forms of environmental threats, e.g. common use of pesticides contributes to emergence of many diseases, and it can also affect the health of future generations (Żak, 2016). The use of high doses of mineral fertilisers also raises public concerns. Ensuring food security is a challenge for the contemporary agriculture, but actions aiming at it ought to be environment-friendly. A factor intensifying agricultural production, which at the same time is harmless to the environment is the introduction of new species of crops, more fruitful and of better quality (resistant to diseases and pests). The cultivation technology should also be improved, to include not only production and economic effects but also safety of the natural environment. 


\section{References:}

Castle, E.N., Becker, M.H. (1971). Zasady podejmowania decyzji w gospodarstwie rolniczym. Warszawa: PWRiL, p. 19.

Coleman, W., Grant, W., Josling, T. (2004). Agriculture in New Global Economy. Wyd. Edward Elgar, Cheltencham-Northampton, p. 51.

Czyżewski, A., Smędzik, K. (2010a). Efektywność techniczna i środowiskowa gospodarstw rolnych w Polsce według typów i klas wielkości w latach 2006-2008. Rocz. Nauk Rol., SERiA G, vol. 97, issue 3, pp. 61-71, as in: Pszczółkowski, T. (1978). Mała encyklopedia prakseologii i teorii organizacji. Wrocław: Zakład Narodowy im. Ossolińskich, p. 60.

Czyżewski, A., Smędzik, K. (2010b). Efektywność techniczna i środowiskowa gospodarstw rolnych w Polsce według typów i klas wielkości w latach 2006-2008. Rocz. Nauk Rol., SERiA G, vol. 97, issue 3, pp. 61-71.

Dincer, I. (2000). Renewable energy and sustainable development: a crucial review. Renewable and Sustainable Energy Reviews, 4, pp. 157-175.

Gębska, M., Filipiak, T. (2006). Podstawy ekonomiki i organizacji gospodarstw rolniczych. Warszawa: SGGW, pp. 59-65.

Jankowiak, J., Bieńkowski, J. (2010). Syntetyczna ocena stanu zrównoważenia produkcyjnego, środowiskowego i ekonomicznego rolnictwa w skali gospodarstwa i region. In: Wilkin, J. (ed.) (2010). Wielofunkcyjność rolnictwa. Kierunki badań, podstawy metodologiczne i implikacje praktyczne. Warszawa: IRWiR PAN, pp. 93-112.

Krasowicz, S., Kopiński, J. (2006). Wpływ warunków przyrodniczych i organizacyjno-ekonomicznych na regionalne zróżnicowanie rolnictwa w Polsce. In: Regionalne zróżnicowanie produkcji rolniczej w Polsce. Program Wieloletni 2005-2010, IUNG-PIB, no. 3, pp. 81-99.

Krasowicz, S., Kuś J. (2006). Regionalne zróżnicowanie produkcji roślinnej w Polsce na tle warunków przyrodniczych i ekonomiczno-organizacyjnych. Wieś Jutra, no. 6, pp. 3-5.

Milewski, R. (ed.) (2008). Elementarne zagadnienia ekonomii. Warszawa: PWN, pp. 187-188.

Popp, J., Hantos, K. (2011). The impact of crop protection on agricultural production. Studies in Agricultural Economics, no. 113, pp. 47-66.

Runowski, H. (2002). Rozwój zrównoważony rolnictwa i gospodarstw rolniczych. In: Wieś i rolnictwo perspektywy rozwoju. Warszawa: IERiGŻ, IRWiR PAN, SGH, pp. 139-156.

Samuelson, P.A., Nordhaus, W.D. (1995). Ekonomia 1. Warszawa: PWN, pp. 704-713.

Skarżyńska, A., Goraj, L., Ziętek, I. (2005). Metodologia SGM „2002” dla typologii gospodarstw rolnych w Polsce. Program Wieloletni 2005-2009, no. 5, Warszawa: IERiGŻ-PIB.

Skarżyńska, A. (2010). Zagadnienia metodyczne rachunku kosztów ekonomicznych na przykładzie działalności produkcji roślinnej. Zagadnienia Ekonomiki Rolnej, no.3(324), pp. 90-107.

Tubiello, F.N., Soussana, J.F, Howden, S.M. (2007). Crop and pasture response to climate change. PNAS, 104.

Zalewski, A. (2016a). Rynek środków ochrony roślin. In: Rynek środków produkcji dla rolnictwa. Warszawa: IERiGŻ-PIB, ARR, MRiRW, no. 43, pp. 19-20.

Zalewski, A. (2016b). Światowy rynek nawozów mineralnych. In: Rynek środków produkcji dla rolnictwa. Warszawa: IERiGŻ-PIB, ARR, MRiRW, no. 43, p. 18.

Żak, A. (2016), Środki ochrony roślin a zmiany w środowisku naturalnym i ich wpływ na zdrowie człowieka. Zagadnienia Ekonomiki Rolnej, no. 1(246), pp. 155-166. 
ALDONA SKARŻYŃSKA

Instytut Ekonomiki Rolnictwa i Gospodarki Żywnościowej

- Państwowy Instytut Badawczy

Warszawa

\title{
EFEKTYWNOŚĆ TECHNICZNA, EKONOMICZNA I ŚRODOWISKOWA PRODUKCJI WYBRANYCH PRODUKTÓW ROŚLINNYCH W REGIONACH ROLNICZYCH POLSKI
}

\begin{abstract}
Abstrakt
$W$ artykule przedstawiono regionalne zróżnicowanie efektywności technicznej, ekonomicznej $i$ środowiskowej produkcji pszenicy ozimej, żyta ozimego, jęczmienia jarego, rzepaku ozimego oraz buraków cukrowych. W badaniach wykorzystano dane gromadzone w systemie AGROKOSZTY i Polski FADN. Dla pokazania zmian w wynikach badanych działalności analizie poddano średnie czteroletnie. Miara oceny efektywności technicznej byta produkcyjność czynników wytwórczych (pracy, ziemi i kapitału), a efektywności ekonomicznej - wskaźnik opłacalności wyrażajacy relację wartości produkcji do kosztów ekonomicznych. Natomiast efektywność środowiskowa opisuja wskaźniki pokazujące koszt oraz poziom nakładów wpływajacych negatywnie na środowisko, tj. nawozów mineralnych (NPK) i środków ochrony roślin.

Wyniki badań wskazują na znaczne różnice regionalne. Techniczna efektywność czynników produkcji $w$ gospodarstwach położonych $w$ regionie Wielkopolska i Ślask oraz Pomorze i Mazury była większa niż na Mazowszu i Podlasiu oraz w regionie Małopolska i Pogórze. Najmniejszym zróżnicowaniem w regionach charakteryzowała się produkcyjność ziemi. Ekonomiczna efektywność produkcji zawierała się w przedziale 97,1-147,5\%. Wskaźnik opłacalności na poziomie 97,1\% zapewnito żyto uprawiane w regionie Małopolska i Pogórze. Jego wysokość oznacza, że koszty ekonomiczne nie zostały w petni pokryte. Dla pełnego pokrycia kosztów ekonomicznych konieczny bytby wzrost plonu lub ceny ziarna żyta o 4,5\%. Regionalne zróżnicowanie zastosowanej dawki nawozów NPK przy uprawie żyta było 1,4-krotne, a w przypadku pozostałych ziemiopłodów - 1,1-krotne.

Natomiast koszt środków ochrony roślin bardziej różnit się regionalnie. Zróżnicowanie 1,1-krotne odnotowano tylko w odniesieniu do buraków cukrowych, w przypadku pszenicy i jęczmienia było 1,2-krotne, rzepaku ozimego-1,3-krotne, a żyta-2,3-krotne. W regionie Pomorze i Mazury oraz Wielkopolska i Ślask koszt środków ochrony roślin oraz nawozów NPK w przeliczeniu na 1 ha uprawy badanych działalności na ogót był wyższy niż w regionie Mazowsze i Podlasie oraz Małopolska i Pogórze.
\end{abstract}


Słowa kluczowe: techniczna efektywność czynników produkcji, opłacalność produkcji, efektywność środowiskowa, koszty ekonomiczne produktów rolniczych, dochód z zarządzania.

Accepted for print: 27.04.2017.

Unless stated otherwise all the materials on the website are available under the Creative Commons Attribution 3.0 Poland license. Some rights reserved to the Institute of Agricultural and Food Economics - National Research Institute. 